\title{
An efficient micropropagation protocol for direct organogenesis from nodal explants of medicinal climber, Tylophora indica
}

\author{
Rafeeq Ahmad Najar*, Mufida Fayaz, Musadiq Hussain Bhat, Mudasir Bashir, Amit Kumar
} and Ashok Kumar Jain

School of Studies in Botany, Jiwaji University Gwalior (M.P.), India- 474011

\section{ABSTRACT}

This study aimed at in vitro multiplication of Tylophora indica (Burm F.) Merill.via direct shoot regeneration. Initially, screening was done for the analysis of different explants for their competence for direct shoot regeneration. The explants were cultured on media supplemented with eight different concentrations $\left(0.5,1.0,1.5,2.0,2.5,3.0,3.5\right.$ and $\left.^{4.0} \mathrm{mgl}^{-1}\right)$ of each cytokinin separately and the concentrations of each cytokinin with highest responses were used in combination with IAA $\left(0.1,0.25\right.$ and $\left.0.50 \mathrm{mgl}^{-1}\right)$ and IBA $\left(0.1,0.25\right.$ and $\left.0.50 \mathrm{mgl}^{-1}\right)$. Nodal explants revealed the maximum capacity for direct shoot regeneration among all the explants tested. Following the direct shoot emergence, explants were shifted for subculturing on shoot proliferation media. The medium supplemented with TDZ $\left(1.5 \mathrm{mgl}^{-1}\right)$ proved effective for achieving optimum number of shoots with appropriate length. The rooting medium supplemented with $0.5 \mathrm{mg} / \mathrm{l} \mathrm{IBA}$ resulted in maximum number of roots per shoot. Rooted plantlets were successfully hardened in the growth room and later established in the greenhouse. The survival rate of the plants was recorded as 90\%. Plants showed no morphological variations.

KEY WORDS: ORGANOGENESIS, NODAL EXPLANTS, PLANT GROWTH REGULATOR, REGENERATION, TYLOPHORA INDICA

\section{INTRODUCTION}

In developing countries like India, medicinal plants continue to be the main source of medication. Indian subcontinent is a vast reservoir of medicinal plants that are used in traditional medical treatments (Chopra et al.,
1986). Herbal medicines are fairly safe remedies and this approach of health care is increasing frequently as the products employed are non toxic with fewer side effects, better compatibility and affordability (Dubey et al., 2004; Sharma et al., 2008; Philomena, 2011). The demand of medicinal plants has necessarily increased due to resur-

\section{ARTICLE INFORMATION:}

*Corresponding Author: tclabju17@gmail.com Received $19^{\text {th }}$ Jan, 2018

Accepted after revision $28^{\text {th }}$ March, 2018

BBRC Print ISSN: 0974-6455

Online ISSN: 2321-4007

Thomson Reuters ISI ESC / Clarivate Analytics USA and

Crossref Indexed Journal

NAAS Journal Score 2017: 4.38 SJIF 2017: 4.196

- A Society of Science and Nature Publication, Bhopal India 2018. All rights reserved.

Online Contents Available at: http//www.bbrc.in/

DOI: $10.21786 / \mathrm{bbrc} / 11.1 / 20$ 
rection of public interest in plant-based medicines coupled with swift expansion of pharmaceutical industries (IMS, 2015).

The genus Tylophora comprises 60 species that are mainly distributed in tropical and subtropical Asia, Africa and Australia. Tylophora indica (Burm f.) Merill.is an important threatened medicinal plant commonly known as Antmul. Medicinally Tylophora indica is an important plant and very efficiently used in all the systems of medicine. It is a perennial, small, slender, much branched pubescent twining or climbing herb found in the subHimalayan tract from Uttar Pradesh to Meghalaya and in the central and peninsular India. It has also been reported from Eastern, North-East and Central India, Bengal and parts of South India (Gupta, 2003). It is also found in Ceylon, Malay island and Borneo. It is traditionally used as a folk remedy in certain regions of India for the treatment of bronchial asthma, inflammation, allergies, rheumatism and dermatitis. Its antitumor, immunomodulatory, antioxidant, antiasthmatic, smooth muscle relaxant, antihistaminic, hypotensive, antirehumatic activities are scientifically proven. In Ayurveda, the plant has been used in treatment of asthma, dermatitis and rheumatism (Anonymous, 1978 and Chopra et al., 1986).

The other reported activities include immune modulatory activity, antioxidant and free radical scavenging activity (Mohan et al., 2014, Ranemma et al., 2017), anti-inflammatory activity (Ravikumar and Abbulu, 2011), hepatoprotective activity (Mujeeb et al., 2009), antibacterial activity (Ranemma et al., 2017), anticancer activity (Vijayakumari et al., 2014), antianxiety activity (Rao et al., 2013; Mannikoth et al., 2016), anticonvulsant activity (Hafis et al., 2017), antiamoebic activity (Ganguly et al., 2001; Haung, 2004) and anti asthmatic activity (Umamaheshwari et al, 2017). The active constituents of Tylophora indica are alkaloids like tylophorine, tylophorinine, tylophorinidine and septidine and non-alkaloidal compounds like kaempferol, quercetin, $\alpha$ - and $\beta$-amyrins, tetratriacontanol, octaosanyloctacosanoate, sigmasterol, $\beta$-sitosetrol, tyloindane, wax, resin, and tannins (Rout et al., 2012; Saraswati et al., 2013; Mohan et al., 2014; Joy et al., 2017).

For in vitro regeneration of this plant, the effect of various growth regulators have been analysed from time to time and plant has been micropropagated successfully in different parts of the world (Nema et al., 2007; Sahai et al., 2007; Rani and Rana, 2010; Davendra et al, 2011; Kaur et al, 2011; Mohan et al., 2014). In India it has also been regenerated in in vitro conditions but still its micropropagation is in vague in some important regions of India. Particularly the plant being among the threatened plant species and in different regions where the physiological conditions are unusual, therefore, a protocol must be standardized to cope with the alarm- ing situations. Direct regeneration has been reported to vary with concentrations and combinations of hormones, light and incubation, genotype and explant used (Parveen and Shahzad, 2014; Niedz et al., 2015).

Hence, it is important to standardize the culture conditions to achieve direct regeneration in desired genotypes. Therefore, the objective of the present study was to investigate the responses of $T$. indica nodal explants in vitro to growth regulators at a range of concentrations and in different combinations in order to identify optimum conditions for adventitious regeneration of shoots from nodal explants and acclimatize and transfer to green house.

\section{MATERIAL AND METHODS}

Collection of plant material: The plants were collected from Chambal eco-region and grown in the Medicinal Plant Garden, Jiwaji University Gwalior, Madhya Pradesh, India. Plant specimen prepared by standard method was submitted to Herbarium of Institute of Ethnobiology, Jiwaji University Gwalior, India, where it was taxonomically identified (IOE-235).

Surface sterilization: Healthy nodes were collected from field grown plants as an explant source. After washing with running tap water, the leaves were trimmed off and nodes were washed for 15 minutes under continuous stream of running tap water. Explants were soaked for 3 minutes in 1\% Tween 20 detergent (polyoxyethylene sorbitan monolaurate; Sigma chemicals Co., St. Louis, MO, USA) and were rinsed with distilled water, then were treated with 2\% Bavistin (Carbendazium 50\% WP; BASF India Limited) for 5 minutes and finally surface sterilized with $0.1 \% \mathrm{HgCl}_{2}$ for 3 minutes and rinsed four times with autoclaved double distilled water under aseptic conditions in laminar chamber. Surface sterilized explants were transferred to sterilized petridishes. 0.5 $\mathrm{cm}$ long explants were cut and inoculated on culture media supplemented with different concentrations and combinations of growth regulators.

Culture medium: Surface sterilized explants $0.5 \mathrm{~cm}$ long were transferred to sterilized petri dishes in laminar chamber and inoculated on Murashige Skoog's (MS) medium containing $3 \%$ sucrose and gelled with $0.8 \%$ agar supplemented with various concentrations auxins and cytokinins like BAP, TDZ, KIN, IBA and IAA for shoot and IBA and NAA for root initiation. The $\mathrm{pH}$ of the medium was adjusted to 5.75 using $0.1 \mathrm{~N} \mathrm{NaOH}$ or $0.1 \mathrm{~N} \mathrm{HCl}$ before autoclaving for $20 \mathrm{~min}$ at $121{ }^{\circ} \mathrm{C}$ and $15 \mathrm{lbs}$ pressure.

Culture conditions: Cultures were incubated at $(25 \pm 2)$ ${ }^{\circ} \mathrm{C}$ and 60\%-70\% relative humidity, and light intensity 
2500 lux with a photoperiod of $16 \mathrm{~h}$ light and $8 \mathrm{~h}$ dark. Each experiment was conducted twice with 10 replicates per treatment. In the in vitro cultures of Tylophora indica, sub-culturing was done after every 30 days on the same media. All the cultures were observed regularly; contaminated cultures were discarded at the earliest and were autoclaved. The cultures were observed for the effect of media adjuvant with different growth regulators and organic supplements on in vitro regeneration. All the cultures established for in vitro shoot regeneration were monitored for percentage shoot induction, average number of shoots per explant and average shoot length.

In vitro rooting of shoots: For rooting of in vitro induced shoots, half strength MS media supplemented with indole-3-butyric acid (IBA) or $\alpha$-naphthalene acetic acid (NAA) at 0.50, 1.00 and $1.50 \mathrm{mgl}^{-1}$, were used as rooting media. Shoots of $1.0-1.5 \mathrm{~cm}$ were excised from multiple shoots and then cultured in rooting media. Data were recorded on percentage of rooting and the number and length of roots/shoots after four weeks of culture. Rooted plantlets of about $6 \mathrm{~cm}$ in length were washed thoroughly in running tap water, and transplanted into autoclaved plastic pots filled with mixture of sand, soil and manure in 1:2:1 ratio under artificial light in 16 $\mathrm{h} / 8 \mathrm{~h}$ photoperiod conditions covered with polythene bags to maintain humidity and then kept in the laboratory. After two weeks, the pots were transferred to a greenhouse under $30{ }^{\circ} \mathrm{C}$ with $60 \%$ relative humidity and were watered daily. The regenerated plantlets were acclimatized for 4-8 weeks and then successfully transferred to the soil under normal conditions. The percentage of survival explants, percentage of shoot response, shoot length, shoot initiation time, shoot number, root response percentage, root initiation time and number of roots were recorded after every 14 days. The data was analysed by using statistical ez Anova version 2. The data are presented as Mean \pm Standard error of two replicates.

\section{RESULTS AND DISCUSSION}

Tissue culture acts as a tool for propagation and conservation of most of valuable plant species (Gantait et al., 2011; Khan et al., 2012). The microcolonal propagation of plants is influenced by some important and concomitant factors such as media composition, plant growth regulators, tissue sensitivity and culture environment. Using different combinations of growth regulators and appropriate growing environment, the important plant species can be regenerated. The aim of the present study was to investigate the effect of some important growth regulators on an important endangered medicinal plant species Tylophora indica under in vitro conditions with a view to develop an efficient, reliable and reproducible protocol for its clonal propagation. During the study, out of all the explants used, only nodes were able to show response of shoot induction and caulogenesis which is contradictory with the earlier reports (Thomas and Philip, 2005; Verma et al., 2010) where leaf explants showed best results of shoot induction response.

In the present endeavour there were three different cytokinins viz; Benzyl amino purine (BAP), Thidiazuron (TDZ) and Kinetin (Kn) and two auxins viz; Indole acetic acid (IAA) and Indole butyric acid (IBA) used to evaluate their effect on in vitro shoot regeneration. Eight different concentrations $(0.5,1.0,1.5$, 2.0, 2.5, 3.0, 3.5 and $4.0 \mathrm{mgl}^{-1}$ ) of each cytokinin were worked out separately and the concentrations of each cytokinin with highest responses were used in combination with IAA $\left(0.1,0.25\right.$ and $\left.0.50 \mathrm{mgl}^{-1}\right)$ and IBA (0.1, 0.25 and $0.50 \mathrm{mgl}^{-1}$ ).

Explants cultured on MS medium supplemented with different concentration of BAP showed an increase in the percentage shoot induction and average number of shoots per explants with increase in the concentration of BAP from $0.5 \mathrm{mgl}^{-1}$ to $2.5 \mathrm{mgl}^{-1}$ but the average shoot length showed continuous increase with the increase in BAP concentration. A maximum of $78.89 \pm 1.11 \%$ explants cultured on MS media supplemented with BAP

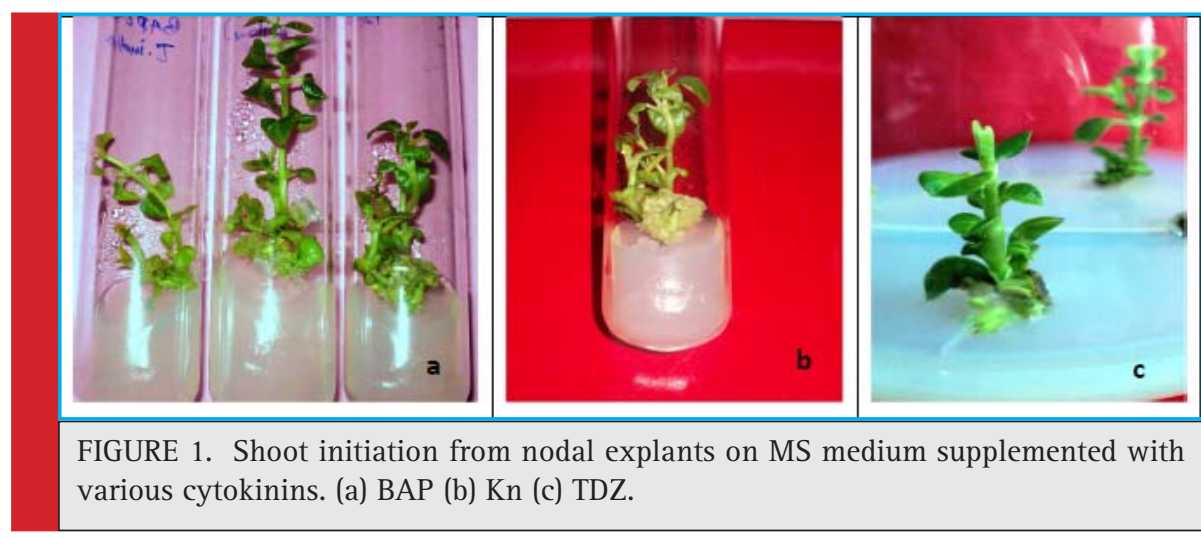

146 AN EFFICIENT MICROPROPAGATION PROTOCOL FOR DIRECT ORGANOGENESIS 


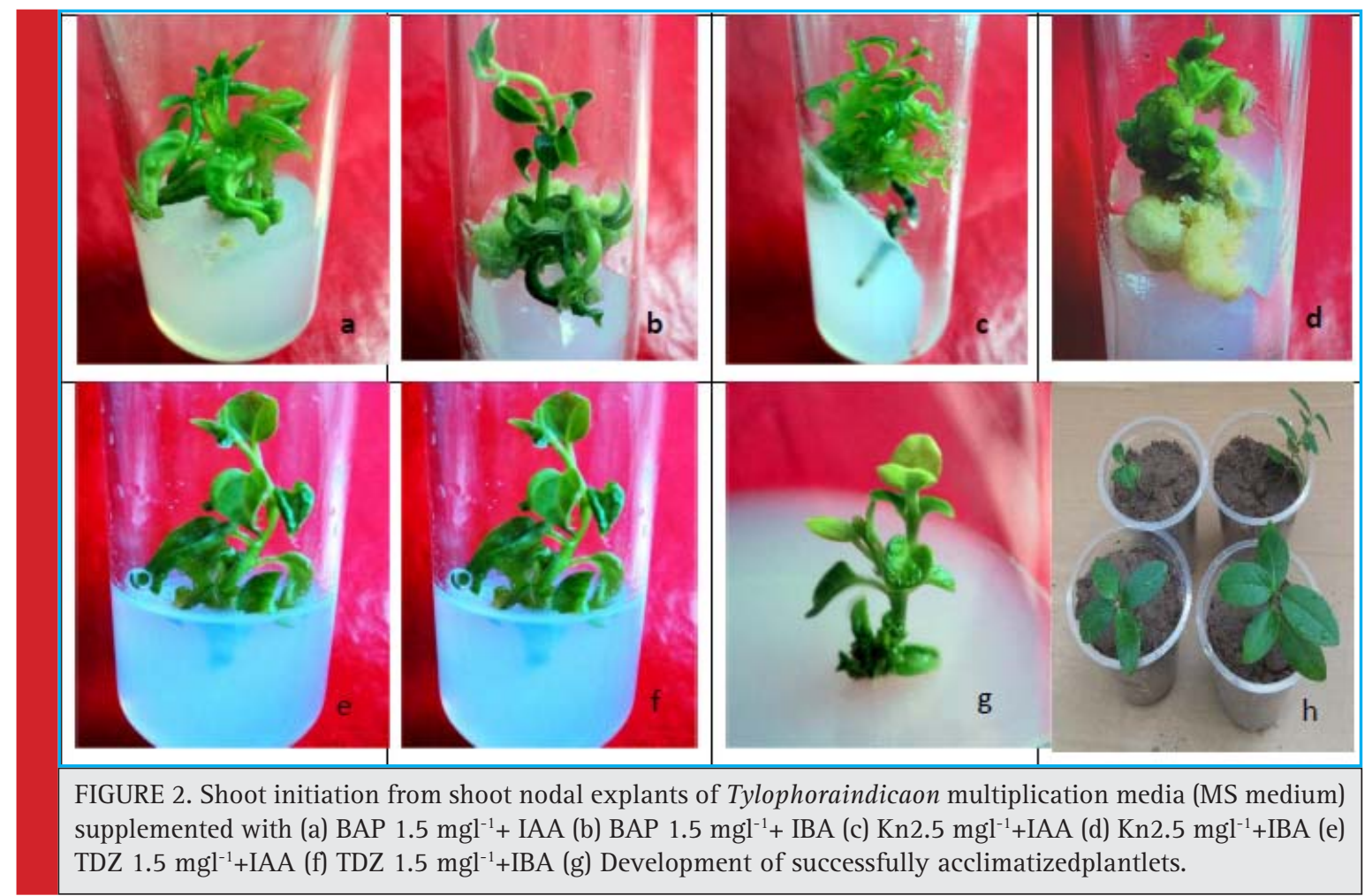

(2.5 $\mathrm{mgl}^{-1}$ ) responded for shoot induction, the highest number of shoots per explants being recorded as $3.60 \pm$ 0.10 (Figure 1a). With further increase in BAP concentration, the percentage shoot induction decreased and average number of shoots per explants also declined. At $4 \mathrm{mgl}^{-1}$ of BAP, the average number shoots were slightly increased up to $2.35 \pm 0.05$.No callus formation was observed (Figures 3-5).

Direct shoot development within 20-21 days of explant inoculation was observed in all the concentrations of $\mathrm{Kn}$ used. The highest percentage of shoot induction (74.44 \pm $14.45 \%$ ) was observed in explants on MS media supple-

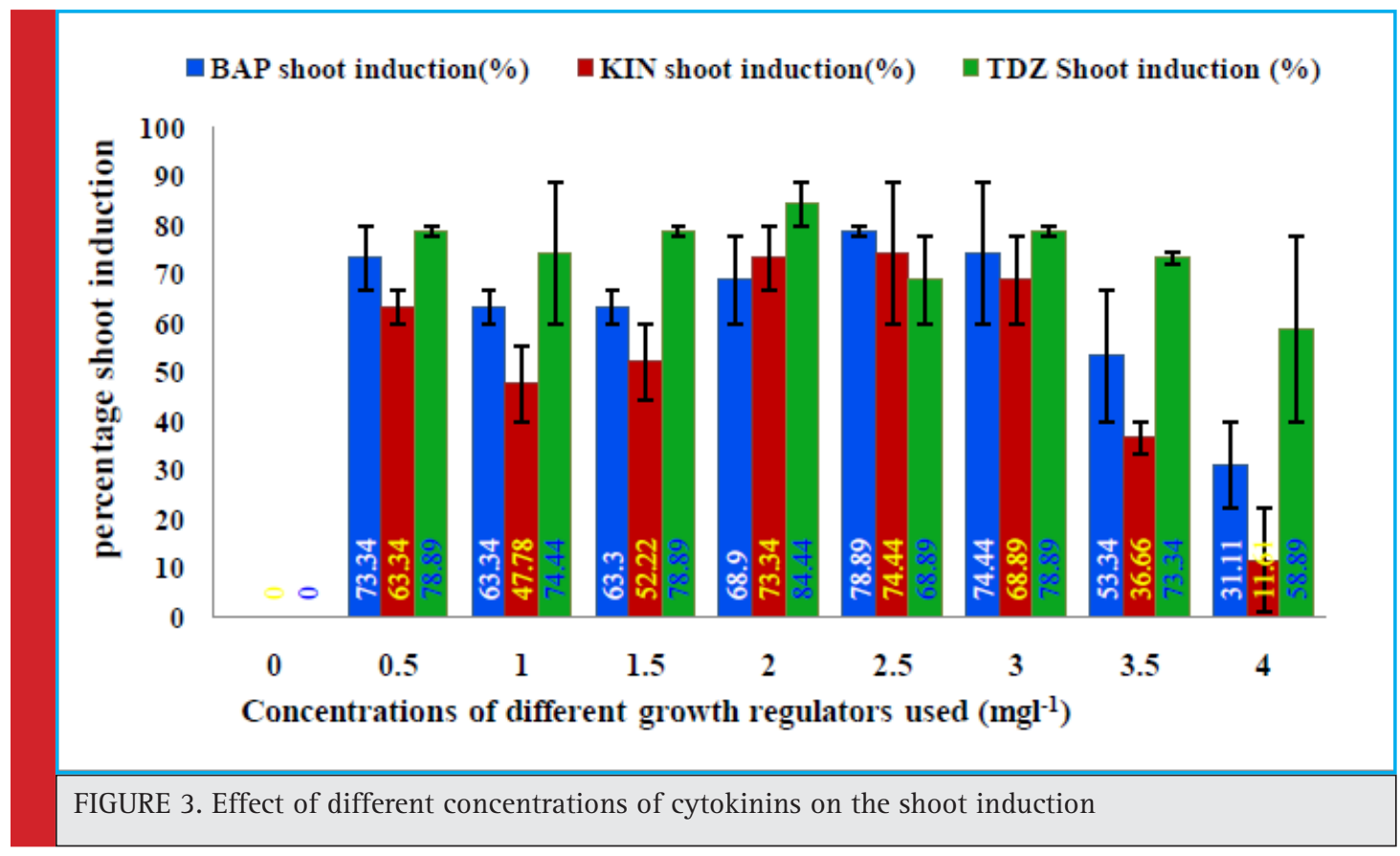




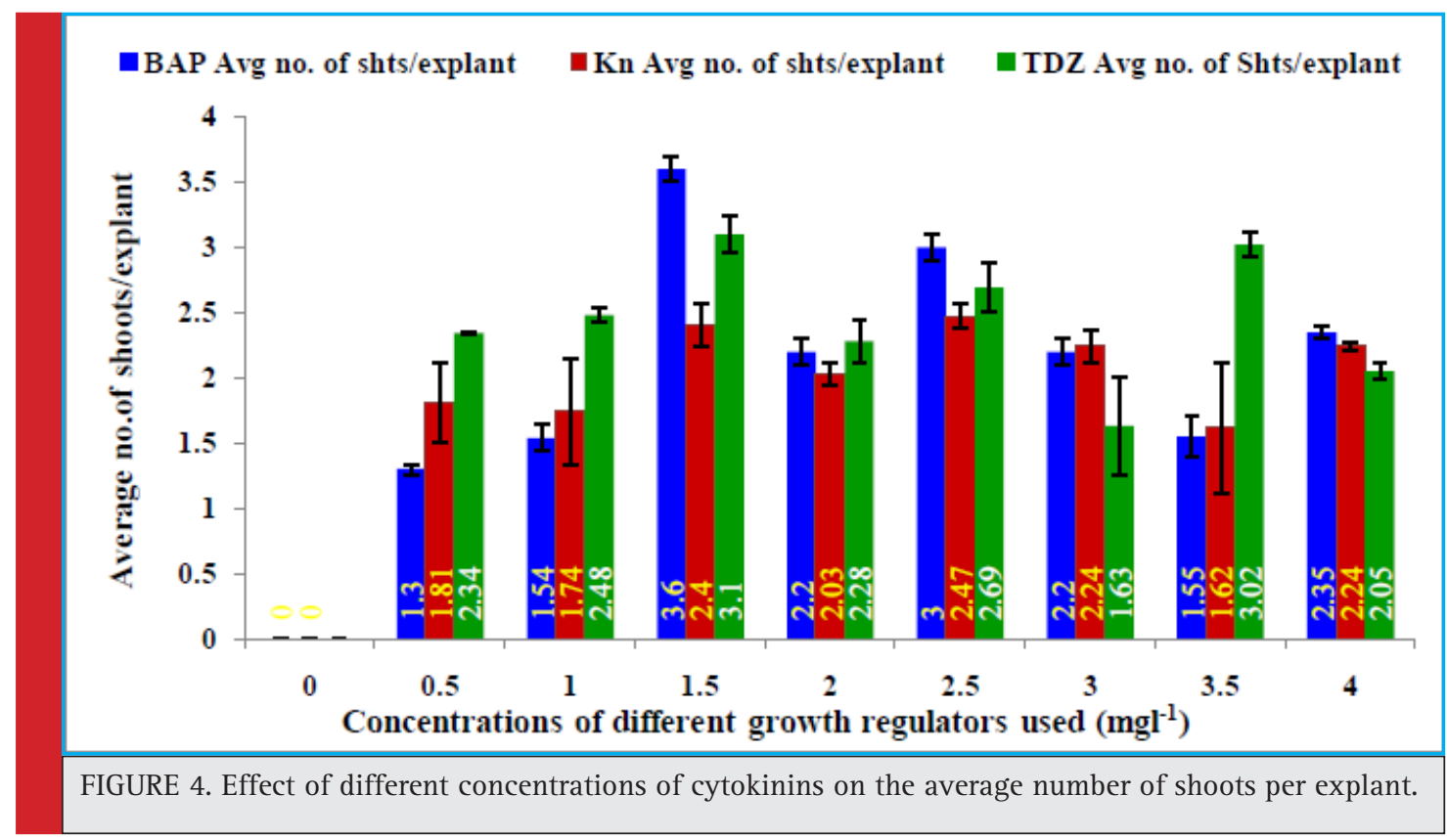

mented with $2.5 \mathrm{mgl}^{-1} \mathrm{Kn}$, with average number of $2.47 \pm$ 0.09 shoots per explants (Figure $1 \mathrm{~b}$ ). Maximum average shoot length $2.70 \pm 0.40 \mathrm{~cm}$ was recorded at $3.5 \mathrm{mgl}^{-1}$. Increase in $\mathrm{Kn}$ concentration in the media results in the decrease of all the facets except the average shoot length which showed irregularity. An increase in the average number of shoots per explant was again observed at 4 $\mathrm{mgl}^{-1}$. No callusing was observed (Figures 3-5).

Fresh explants cultured on MS media supplemented with different concentrations of TDZ responded well in all the facets with a shoot induction percentage upto $84.44 \pm 4.45 \%$ at TDZ $\left(2 \mathrm{mgl}^{-1}\right)$. The explants exhibit

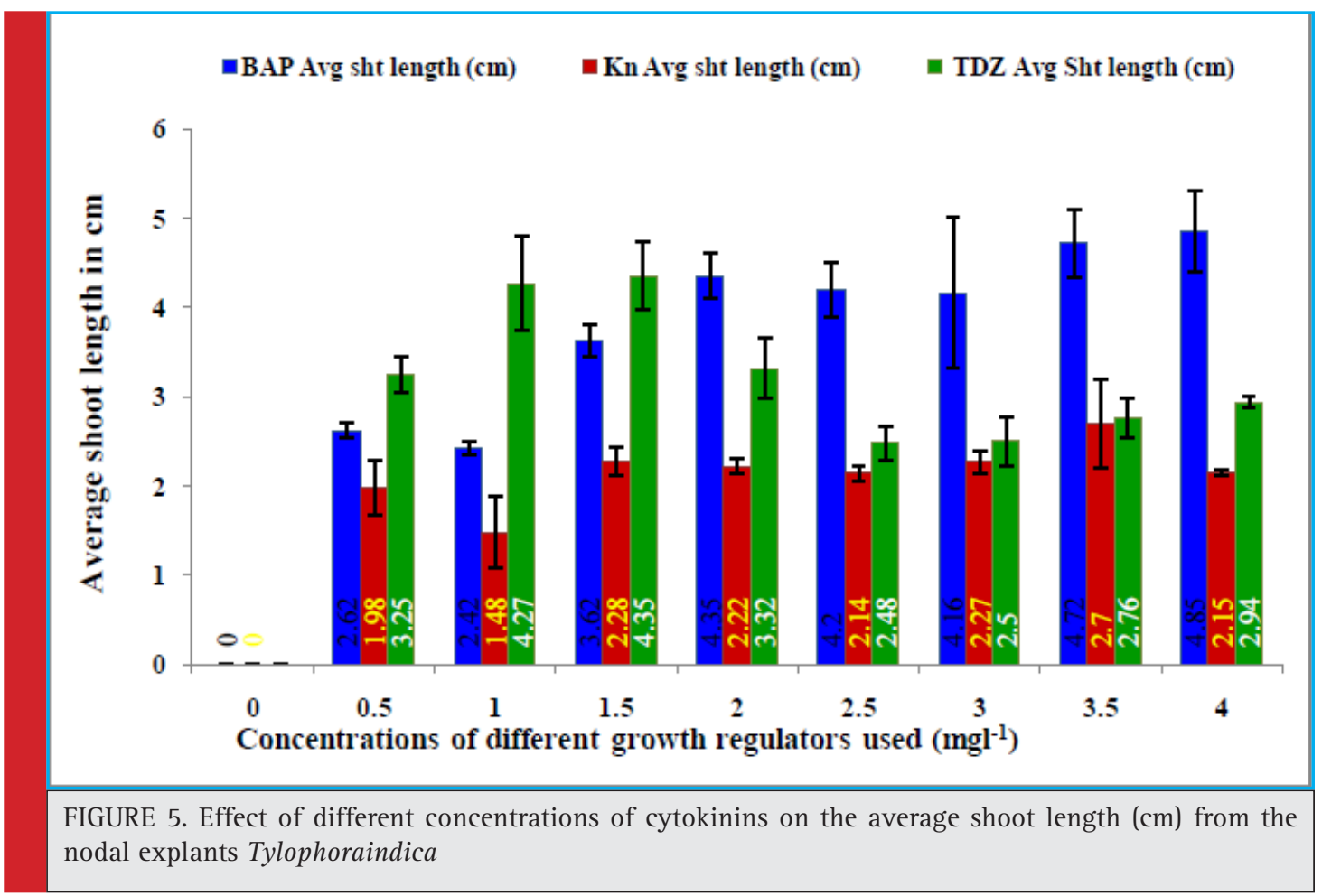

148 


\begin{tabular}{|c|c|c|c|c|c|}
\hline $\begin{array}{l}\text { Conc. of } \\
\text { BAP }\left(\mathrm{mg} \mathrm{l}^{-1}\right)\end{array}$ & $\begin{array}{l}\text { Conc. of } \\
\text { Kin }\left(\mathrm{mg} \mathrm{l}^{-1}\right)\end{array}$ & $\begin{array}{l}\text { Conc. of } \\
\text { TDZ }\left(\mathrm{mg} \mathrm{l}^{-1}\right) \\
\end{array}$ & $\begin{array}{l}\text { Shoot induction } \\
(\%)\end{array}$ & $\begin{array}{l}\text { Number of shoots/ } \\
\text { explants(Mean } \pm \text { S.E) }\end{array}$ & $\begin{array}{l}\text { Average Shoot } \\
\text { length }(\mathrm{cm})\end{array}$ \\
\hline Control & - & - & 0 & $0.0 \pm 0.00$ & 0 \\
\hline 0.5 & - & - & $73.34 \pm 6.6$ & $1.30 \pm 0.04$ & $2.62 \pm 0.08$ \\
\hline 1 & - & - & $63.3 \pm 3.3$ & $1.54 \pm 0.10$ & $2.42 \pm 0.08$ \\
\hline 1.5 & - & - & $63.3 \pm 3.3$ & $3.60 \pm 0.10$ & $3.62 \pm 0.18$ \\
\hline 2 & - & - & $68.9 \pm 8.9$ & $2.20 \pm 0.10$ & $4.35 \pm 0.25$ \\
\hline 2.5 & - & - & $78.89 \pm 1.11$ & $3.00 \pm 0.10$ & $4.20 \pm 0.30$ \\
\hline 3 & - & - & $74.44 \pm 14.45$ & $2.20 \pm 0.10$ & $4.16 \pm 0.84$ \\
\hline 3.5 & - & - & $53.34 \pm 13.33$ & $1.55 \pm 0.15$ & $4.72 \pm 0.38$ \\
\hline 4 & - & - & $31.11 \pm 8.89$ & $2.35 \pm 0.05$ & $4.85 \pm 0.45$ \\
\hline- & 0.5 & - & $63.34 \pm 3.33$ & $1.81 \pm 0.31$ & $1.98 \pm 0.28$ \\
\hline- & 1 & - & $47.78 \pm 7.78$ & $1.74 \pm 0.40$ & $1.48 \pm 0.17$ \\
\hline- & 1.5 & - & $52.22 \pm 7.77$ & $2.40 \pm 0.16$ & $2.28 \pm 0.17$ \\
\hline- & 2 & - & $73.34 \pm 6.66$ & $2.03 \pm 0.09$ & $2.22 \pm 0.11$ \\
\hline- & 2.5 & - & $74.44 \pm 14.45$ & $2.47 \pm 0.09$ & $2.14 \pm 0.21$ \\
\hline- & 3 & - & $68.89 \pm 8.89$ & $2.24 \pm 0.13$ & $2.27 \pm 0.32$ \\
\hline- & 3.5 & - & $36.66 \pm 3.34$ & $1.62 \pm 0.5$ & $2.70 \pm 0.40$ \\
\hline- & 4 & - & $11.61 \pm 10.61$ & $2.24 \pm 0.03$ & $2.15 \pm 0.03$ \\
\hline- & - & 0.5 & $78.89 \pm 1.11$ & $2.34 \pm 0.01$ & $3.25 \pm 0.20$ \\
\hline- & - & 1 & $74.44 \pm 14.45$ & $2.48 \pm 0.05$ & $4.27 \pm 0.53$ \\
\hline- & - & 1.5 & $78.89 \pm 1.11$ & $3.1 \pm 0.14$ & 4. $35 \pm 0.38$ \\
\hline- & - & 2 & $84.44 \pm 4.45$ & $2.28 \pm 0.17$ & $3.32 \pm 0.33$ \\
\hline- & - & 2.5 & $68.89 \pm 8.89$ & $2.69 \pm 0.19$ & $2.48 \pm 0.19$ \\
\hline- & - & 3 & $78.89 \pm 1.11$ & $1.63 \pm 0.38$ & $2.50 \pm 0.27$ \\
\hline- & - & 3.5 & $73.34 \pm 1.11$ & $3.02 \pm 0.10$ & $2.76 \pm 0.22$ \\
\hline- & - & 4 & $58.89 \pm 18.89$ & $2.05 \pm 0.06$ & $2.94 \pm 0.06$ \\
\hline
\end{tabular}

both callusing and direct shoot induction after 21days of inoculation. Results show increase in percentage shoot induction with increased TDZ concentrations in MS media from $78.89 \pm 1.11 \%\left(0.5 \mathrm{mgl}^{-1}\right)$ to $84.44 \pm 4.45 \%$ $\left(2 \mathrm{mgl}^{-1}\right)$ (Figure 1c). A decrease in percentage shoot induction was observed when TDZ concentration was increased above $2 \mathrm{mgl}^{-1}$. The highest number of shoots per explants $(3.1 \pm 0.14)$ with an average shoot length of $4.35 \pm 0.38 \mathrm{~cm}$ was observed when explants were cultured on MS media supplemented with TDZ (1.5 $\mathrm{mgl}^{-}$ $\left.{ }^{1}\right)$. A decrease in percentage shoot induction, average number of shoots per explant, average shoot length and shoot forming capacity was observed when TDZ concentrations was increased from $2.5 \mathrm{mgl}^{-1}$ and $2 \mathrm{mgl}^{-1}$ respectively (Figures 3-5). The regenerated shoots were thick as compared to the shoot regeneration observed in respective concentrations of BAP and $\mathrm{Kn}$.

Out of the three cytokinins used, TDZ showed maximum results not only because of highest percentage shoot induction, average number of shoots per explants and average shoot length achieved with this cytokinin but also due to callus formation which is treated as another route of tissue culture regeneration of plants which is in contradiction with earlier report by (Anand and Nadha, 2006; Kaur et al., 2011; Haque and Ghosh, 2013), which showed best results on MS medium supplemented with BAP. TDZ has been reported to be the most active cytokinin for shoot induction in plant tissue culture (Siddique and Anis, 2007), and has been effective in terms of shoot regeneration in many recalcitrant species. It has been reported that TDZ-induced morphogenesis depends on the levels of endogenous growth regulators and TDZ modulates the endogenous auxin levels (Petric et al., 2011). In present study $84 \%$ shoot induction was observed which is in contrary with earlier findings (Thomas and Philip, 2005) which showed 100\% shoot induction on MS media rejuvenated with TDZ. The better concentration among the different concentrations of this cytokinin was TDZ $\left(1.5 \mathrm{mgl}^{-1}\right)$ for shoot regeneration from nodal explants of Tylophora indica. In case of BAP and $\mathrm{Kn}$ the better concentrations proved to be were 1.5 $\mathrm{mgl}^{-1}$ and $2.5 \mathrm{mgl}^{-1}$ respectively (Table 1 ). 


\begin{tabular}{|c|c|c|c|c|}
\hline Conc. of harmone & $\begin{array}{l}\text { Conc. of } \\
\text { IAA }\left(\mathrm{mg} \mathrm{l}^{-1}\right)\end{array}$ & $\begin{array}{l}\text { Shoot } \\
\text { induction } \\
(\%)\end{array}$ & $\begin{array}{l}\text { Number of } \\
\text { shoots/ explants } \\
(\text { Mean } \pm \text { S.E) }\end{array}$ & $\begin{array}{l}\text { Average } \\
\text { Shoot length } \\
\text { (cm) }\end{array}$ \\
\hline \multirow{3}{*}{ BAP $\left(1.5 \mathrm{mg} \mathrm{l}^{-1}\right)$} & 0.1 & $41.66 \pm 8.34$ & $3.16 \pm 0.31$ & $3.96 \pm 0.25$ \\
\hline & 0.25 & $50.00 \pm 16.67$ & $2.50 \pm 0.37$ & $4.06 \pm 0.07$ \\
\hline & 0.5 & $58.34 \pm 8.33$ & $2.02 \pm 0.21$ & $3.81 \pm 0.32$ \\
\hline \multirow{3}{*}{$\operatorname{Kin}\left(2.5 \mathrm{mg} \mathrm{l}^{-1}\right)$} & 0.1 & $58.34 \pm 8.33$ & $2.75 \pm 0.35$ & $3.60 \pm 0.06$ \\
\hline & 0.25 & $58.34 \pm 8.33$ & $2.57 \pm 0.45$ & $3.62 \pm 0.39$ \\
\hline & 0.5 & $50.00 \pm 16.67$ & $1.44 \pm 0.21$ & $3.65 \pm 0.67$ \\
\hline \multirow{3}{*}{$\operatorname{TDZ}\left(1.5 \mathrm{mg} \mathrm{l}^{-1}\right)$} & 0.1 & $66.66 \pm 16.67$ & $4.38 \pm 0.40$ & $3.93 \pm 0.71$ \\
\hline & 0.25 & $58.34 \pm 8.33$ & $4.01 \pm 0.45$ & $5.02 \pm 0.76$ \\
\hline & 0.5 & $50.00 \pm 16.67$ & $3.66 \pm 0.45$ & $4.78 \pm 0.56$ \\
\hline
\end{tabular}

Optimum concentration of BAP $\left(1.5 \mathrm{mgl}^{-1}\right)$ was used in combinations with different concentrations of auxins (IAA and IBA) for in vitro shoot regeneration. A maximum of $58.34 \pm 8.33 \%$ explants showed direct shoot induction at BAP $\left(1.5 \mathrm{mgl}^{-1}\right)+$ IAA $\left(0.5 \mathrm{mgl}^{-1}\right)$ (Figure 2a). The highest average number of $3.16 \pm 0.31$ shoots per explant was seen in media suppplemeted with $1.5 \mathrm{mgl}^{-1}$ BAP $+0.1 \mathrm{mgl}^{-1} \mathrm{IAA}$ and maximum average shoot length was at BAP $\left(1.5 \mathrm{mgl}^{-1}\right)+$ IAA $\left(0.25 \mathrm{mgl}^{-1}\right)$ (Table 2).

MS media supplemented with BAP $\left(1.5 \mathrm{mgl}^{-1}\right)$ in combination with different concentrations of IBA showed highest response $(58.33 \pm 8.33 \%)$ at $\operatorname{BAP}\left(1.5 \mathrm{mgl}^{-1}\right)+$ IBA (0.1 and $\left.0.5 \mathrm{mgl}^{-1}\right)$ with an average number of 4.29 \pm 0.76 shoots per explant at BAP $\left(1.5 \mathrm{mgl}^{-1}\right)+$ IBA $(0.5$ $\mathrm{mgl}^{-1}$ ) only and maximum average shoot length at BAP $\left(1.5 \mathrm{mgl}^{-1}\right)+$ IBA $\left(0.1 \mathrm{mgl}^{-1}\right)$ (Figure $\left.2 \mathrm{~b}\right)$. A decrease in percentage shoot induction was observed with addition of different concentrations of IBA to BAP $\left(1.5 \mathrm{mgl}^{-1}\right)$ supplemented to MS media. Apart from the direct shoot regeneration, callus formation was also perceived in this blend at BAP (1.5 mgl-1) + IAA $\left(0.25 \mathrm{mgl}^{-1}\right)$ after culturing (Table 3).

Among different $\mathrm{Kn}$ concentrations, $2.5 \mathrm{mgl}^{-1} \mathrm{Kn}$ was revealed to be much effective over all other concentrations and was used in combinations with different concentrations of auxins (IAA and IBA) for in vitro shoot regeneration using nodal explants. A decrease in percentage shoot induction, average number of shoots per nodal explant was observed by addition of IAA $(0.1,0.25$ and 0.5$) \mathrm{mgl}^{-1}$ to (Kn $2.5 \mathrm{mgl}^{-1}$ ) supplemented MS media (Figure 2c). A maximum of $58.34 \pm 8.33 \%$ explants responded for shoot induction at $\mathrm{Kn}\left(2.5 \mathrm{mgl}^{-1}\right)+$ IAA (0.1 mgl $\mathrm{mg}^{-1}$ and $0.25 \mathrm{mgl}^{-1}$ )(Table 2).Explants cultured on MS media divulged $58.34 \pm 8.33 \%$ shoot induction at $\mathrm{Kn}\left(2.5 \mathrm{mgl}^{-1}\right)+\mathrm{IBA}\left(0.5 \mathrm{mgl}^{-1}\right)$ (Figure $\left.2 \mathrm{~d}\right)$. The highest $4.29 \pm 0.76$ average number of shoots per explant were observed on MS media supplemented with Kn (2.5 mgl-1) + IBA (0.5 $\left.\mathrm{mgl}^{-1}\right)$ (Table 3).

TDZ resulted to be over all better growth regulator among the three cytokinins used. Explants cultured on

\begin{tabular}{|c|c|c|c|c|c|}
\hline Conc. of harmone & $\begin{array}{l}\text { Conc. of IBA } \\
\left(\mathrm{mg} \mathrm{l}^{-1}\right)\end{array}$ & $\begin{array}{l}\text { Shoot induction } \\
(\%)\end{array}$ & $\begin{array}{l}\text { Number of shoots/ } \\
\text { explants(Mean } \pm \text { S.E) }\end{array}$ & $\begin{array}{l}\text { Average Shoot } \\
\text { length }(\mathrm{cm})\end{array}$ & $\begin{array}{l}\text { Callus } \\
\text { formation }\end{array}$ \\
\hline \multirow{3}{*}{ BAP $\left(1.5 \mathrm{mg} \mathrm{l}^{-1}\right)$} & 0.1 & $58.33 \pm 8.33$ & $4.00 \pm 0.87$ & $3.81 \pm 0.19$ & _- \\
\hline & 0.25 & $41.66 \pm 8.34$ & $3.68 \pm 0.69$ & $3.45 \pm 0.45$ & ++ \\
\hline & 0.5 & $58.33 \pm 8.33$ & $4.29 \pm 0.76$ & $3.39 \pm 0.28$ & _ \\
\hline \multirow{3}{*}{$\operatorname{Kin}\left(2.5 \mathrm{mg} \mathrm{l}^{-1}\right)$} & 0.1 & $50.00 \pm 16.67$ & $3.05 \pm 0.19$ & $3.47 \pm 0.19$ & - \\
\hline & 0.25 & $41.66 \pm 8.34$ & $2.07 \pm 0.21$ & $3.26 \pm 0.73$ & - \\
\hline & 0.5 & $58.34 \pm 8.33$ & $2.99 \pm 0.13$ & $2.97 \pm 0.61$ & - \\
\hline \multirow{3}{*}{$\operatorname{TDZ}\left(1.5 \mathrm{mg} \mathrm{l}^{-1}\right)$} & 0.1 & $75.00 \pm 8.33$ & $5.84 \pm 0.72$ & $3.85 \pm 0.50$ & + \\
\hline & 0.25 & $58.34 \pm 8.33$ & $4.19 \pm 0.44$ & $2.30 \pm 1.54$ & +++ \\
\hline & 0.5 & $58.34 \pm 8.33$ & $4.30 \pm 0.46$ & $5.14 \pm 0.15$ & +++ \\
\hline
\end{tabular}




\begin{tabular}{|c|c|c|c|c|}
\hline IBA $\left(\mathrm{mg} \mathrm{l}^{-1}\right)$ & NAA (mg l-1) & $\begin{array}{l}\text { Root induction } \\
(\%)\end{array}$ & $\begin{array}{l}\text { Mean number of } \\
\text { roots/ explants }\end{array}$ & $\begin{array}{l}\text { Average root } \\
\text { length }(\mathrm{cm})\end{array}$ \\
\hline 0.5 & - & 90 & $3.25 \pm 0.25$ & $3.87 \pm 0.37$ \\
\hline 1 & - & 75 & $1.75 \pm 0.25$ & $2.25 \pm 0.14$ \\
\hline 1.5 & - & 40 & $1.5 \pm 0.28$ & $1.5 \pm 0.28$ \\
\hline- & 0.5 & 85 & $3.4 \pm 0.4$ & $3.7 \pm 0.2$ \\
\hline- & 1 & 60 & $2.6 \pm 0.2$ & $2.8 \pm 0.25$ \\
\hline- & 1.5 & 30 & $2 \pm 0.54$ & $1.8 \pm 0.25$ \\
\hline
\end{tabular}

MS media showed $66.66 \pm 16.67 \%$ shoot induction at $\operatorname{TDZ}\left(1.5 \mathrm{mgl}^{-1}\right)+\mathrm{IAA}\left(0.1 \mathrm{mgl}^{-1}\right)$. The highest $4.38 \pm 0.40$ average number of shoots per explant were obtained on MS media supplemented with TDZ $\left(1.5 \mathrm{mgl}^{-1}\right)+$ IAA (0.1 $\left.\mathrm{mgl}^{-1}\right)$. Maximum average shoot length was obtained at TDZ $\left(1.5 \mathrm{mgl}^{-1}\right)+$ IAA $\left(0.25 \mathrm{mgl}^{-1}\right)$ (Figure 2e). With increase in the concentration of IAA to TDZ $\left(1.5 \mathrm{mgl}^{-1}\right)$, increase in the percentage shoot induction and average number of shoots per explants was seen but the average shoot length at TDZ $\left(1.5 \mathrm{mgl}^{-1}\right)+\mathrm{IAA}\left(0.25 \mathrm{mgl}^{-1}\right)$ increases up to $5.02 \pm 0.76 \mathrm{~cm}$ and then decreases at TDZ (1.5 mgl-1) + IAA (0.25 $\left.\mathrm{mgl}^{-1}\right)$ (Table 2). The explants exhibit both direct shoot induction and callusing after 21 days but callus formation took place very late after 30 to 35 days from the date of inoculation. A maximum of $75.00 \pm 8.33 \%$ percentage shoot induction with 5.84 \pm 0.72 average number of shoots per explant on media at TDZ $\left(1.5 \mathrm{mgl}^{-1}\right)+\mathrm{IBA}\left(0.1 \mathrm{mgl}^{-1}\right)$. The highest average shoot length was observed at TDZ $\left(1.5 \mathrm{mgl}^{-1}\right)+$ IBA $(0.5$ $\mathrm{mgl}^{-1}$ ) (Figure 2f). Decrease in percentage shoot induction and average number of shoots per explant was observed with increase in the concentration of IBA to TDZ (1.5 $\left.\mathrm{mgl}^{-1}\right)$. The average shoot length slightly decreased with increase in the concentration of IBA from 0.1 to 0.25 $\mathrm{mgl}^{-1}$ on MS media and increases largely at TDZ (1.5 $\left.\mathrm{mgl}^{-1}\right)+$ IBA $\left(0.1 \mathrm{mgl}^{-1}\right)$. Large amount of callus formation was observed when media was added with TDZ (1.5 $\left.\mathrm{mgl}^{-1}\right)+$ IBA (0.25 to $0.5 \mathrm{mgl}^{-1}$ ) (Table3).

In vitro shoot regeneration response from nodal explants was not significant when different concentrations of Auxins (IAA and IBA) were added to MS media fortified with combination of BAP $\left(1.5 \mathrm{mgl}^{-1}\right)$ and $\mathrm{Kn}$ $\left(2.5 \mathrm{mgl}^{-1}\right)$. The percentage shoot induction decreased with addition of these auxins but slight increase in the average number of shoots per explant and average shoot length was observed. Thus the micropropagation protocol for shoot induction developed for Tylophora indica can be successfully applied for large scale multiplication. For root induction, elongated shoots were subcultured for more than 5 weeks on medium containing TDZ. Both the auxins IBA and NAA supplemented to half strength
MS medium initiated rooting. Maximum of 90\% rooting was observed on medium with half strength basal salts containing $0.5 \mathrm{mgl}^{-1} \mathrm{IBA}$ with $90 \%$ rooting percentage, strong and good number of roots (Table 4).

Regenerated rooted plantlets were successfully transferred to pots containing soil, sand and manure in a 2:1:1 ratio. The pots containing plantlets were kept in growth room for 2 weeks and then transferred to green house. Healthy plantlets from pots were then transferred after 6-8 to field conditions for survival. Survival rate of $90 \%$ was observed. Plants were found to be similar to mother plants (Figure 2g).

The results of this study revealed that nodal explants had the highest regeneration rate in MS medium supplemented with various plant growth regulators. Furthermore, our results showed that TDZ was more effective among the cytokinins in shoot regeneration. TDZ in combination with IBA also showed good results with average number of shoots powered to 5-6 shoots per explants and at the same concentration best performance of callusing was witnessed. Half strength Basal medium with IBA was found most effective for root formation of $T$. indica when compared with NAA. Hence a protocol has been developed through for in vitro shoot regeneration and root regeneration under in vitro conditions to fulfil the natural reservoir of this plant and needs of pharmaceutical industries in future.

\section{ACKNOWLEDGEMENTS}

Authors are grateful to Honorary Director, Institute of Ethnobiology and Head, School of Studies in Botany, Jiwaji University, Gwalior for providing needed facilities for the research.

\section{REFERENCES}

Anand M and Nadha HK. (2006). Clonal Propagation of Tylophora indica- An important Medicinal Plant through Tissue Culture. A Desertation Report: Department of Biotechnol- 
ogy and Environmental Sciences, Thapar Institute of Engineering and Technology Patiala, India.

Anonymous. (1978). The wealth of India. NISCAIR, CSIR, New Delhi: 398- 399.

Chopra IC, Chopra RN and Nayar SL. (1986). Glossary of Indian medicinal plants. CSIR, New Delhi: 5-10.

Devendra BN, Srinivas N and Naik GR. (2011). Direct somatic embryogenesis and synthetic seed production from Tylophora indica (Burm. f.) Merrill an endangered, medicinally important plant. International Journal of Botany. 7(3), 216-222.

Dubey NK, Kumar R and Tripathi P. (2004). Global promotion of herbal medicine: India's opportunity. Curr. Sci. 86, 37-41.

Gantait S, Mandal N and Nandy S. (2011). Advances in micropropagation of selected aromatic Plants: A review on Vanilla and Strawberry. American J Biochem and Mol Biol. 1(1), 1-19.

Gupta AK. (2003). Quality standards of Indian medicinal plants. ICMR. 1, 221- 225.

Hafis TK, Manikkoth SK, Sequeira M, Nayak RP. (2017). Pharmacological evidence for the anticonvulsant activity of Tylophora indica in experimental animal models. Int J Basic Clin Pharmacol. 6,750-753.

Haque SM and Ghosh B. (2013). Field evaluation and genetic stability assessment of regenerated plants produced via direct shoot organogenesis from leaf explant of an endangered 'Asthma Plant'(Tylophora indica) along with their in vitro conservation. National Academy Science Letters. 36(5), 551562.

IMS Health. (2015). Global medicines use in 2020: Outlook and Implications. www.theimsinstitute.org.

Joy Minnu, Lakshmi VV, Krishna Priya KA and Sruthy VS. (2017). Phytochemical screening and evaluation of in vitro antiulcer activity of Tylophora indica (Burm. f.) Merrill. International Journal of Institutional Pharmacy and Life Sciences. 7(2),51-55.

Kaur H, Anand M and Goyal D. (2011). Establishment of an efficient protocol for micropropagation of stem explants of Tylophora indica, an important medicinal plant. African Journal of Biotechnology. 10(36), 6928-6932.

Khan S, Qurainy FA and Nadeem M. (2012). Biotechnological approaches for conservation and improvement of rare and endangered plants of Saudi Arabia. Saudi J Biol Sci. 19,1-11.

Mannikoth S, Deepa B, Sequeira M, Joy AE, Rodrigues R. (2016). Assessment of brain dopamine levels to evaluate the role of Tylophora indica ethanolic extract on alcohol induced anxiety in Wistar albino rats. J Young Pharm. 8,91-95.

Mohan SM, Narayan VR, Abhijeet S, Amla B. (2014). Antioxidant and free radical scavenging properties of Tylophora indica (Burm. F.) Merrill an anti-asthmatic plant. Asian J Pharm Clin Res. 7,174-6.

Mujeeb M, Aeri V, Bagri P and Khan SA. (2009). Hepatoprotective activity of the methanolic extract of Tylophora indica (Burm. f.) Merill. leaves. International Journal of Green Pharmacy (IJGP). 3(2),125-127.
Nema RK, Ramawat KG, Gupta GD, Tanwar YS and Mathur M. (2007). Rapid micropropagation of Tylophora indica. Pharmacognosy Magazine. 3(9), 52.

Niedz RP, Albano JP and Marutani-Hert M. (2015). Effect of various factors on shoot regeneration from citrus epicotyl explants. Journal of Applied Horticulture.17(2), 121-128.

Parveen S and Shahzad A. (2014). Factors affecting in vitro plant regeneration from cotyledonary node explant of Senna sophera (L.) Roxb.-A highly medicinal legume. African Journal of Biotechnology. 13(3).

Petrić M, Subotić A, Jevremović S, Trifunović M. 2011. Somatic embryogenesis and bulblet regeneration in snakehead fritillary (Fritillaria meleagris L.). Afr J Biotechnol. 10(72),1618116188.

Philomena G. (2011). Concerns regarding the safety and toxicity of medicinal plants - An overview. J Appl Pharmaceut Sci. 01(6), 40-44.

Ranemma M, Nagendram E, Niranjan S, Reddy AN and Mohan C. (2017). Phytochemical Analysis, Antibacterial and Antioxidant Activity of Tylophora indica. Int. J. Curr. Microbiol. App. Sci. 6(2),487-493.

Rani S and Rana JS. (2010). In vitro propagation of Tylophora indica-influence of explanting season, growth regulator synergy, culture passage and planting substrate. J Am Sci. 6(12), 386-392.

Rao SN, Mannikoth S, Chandrashekhar R. (2013). Antianxiety effect of ethanolic extract of leaves of Tylophora indica in wistar albino rats. Int J Res Ayurveda Pharm. 4,127-9.

Ravikumar A and Abbulu K. (2011). Evaluation of antiinflammatory activity of Calotropis gigantea, Tylophora indica and Sarcostemma secomone. Int Res J Pharm Appl Sci. 1,3442.

Rout S, Rout S and Ghadai A. (2012). Phytoceutical evaluation and antimicrobial properties of Eclipta alba and Tylophora indica. Int J Microbiol Res. 4(5),227-230.

Sahai A, Shahzad A, and Anis M. (2010). High frequency plant production via shoot organogenesis and somatic embryogenesis from callus in Tylophora indica, an endangered plant species. Turkish Journal of Botany. 34(1), 11-20.

Sharma A, Shanker C, Tyagi LK, Singh M and Rao CV. (2008). Herbal medicine for market potential in India: An overview. Acad J Plant Sci. 1, 26-36.

Sharma MM, Verma RN, Singh A, and Batra A. (2014). Assessment of clonal fidelity of Tylophora indica (Burm. f.) Merrill "in vitro" plantlets by ISSR molecular markers. Springer Plus. 3(1),400.

Siddique I, Anis M. (2007). Rapid micropropagation of Ocimum basilicum using shoot tip explants pre-cultured in thidiazuron supplemented liquid medium. Biol Plant. 51,787-790.

Thomas TD and Philip B. (2005). Thidiazuron induced highfrequency shoot organogenesis from leaf derived callus of a medicinal climber, Tylophora indica. In vitro cellular and Development Biology- Plant 41, 124-128. 
Umamaheswari P, Sailaja V, Ravanaiah G, Kumar PD and Murthy CV. (2017). Role of Tylophora indica in Treatment of bronchial asthama. International Journal of Life Science and Pharma Research. 7(1),17-21.

Verma RN, Jamal SM, Sharma MM, Rao DV and Batra A. (2010). Regulation of organogenesis using leaf, internode and petiole explants in Tylophora indica (Burm. f.) Merr. Int J Pharma Sci Rev Res. 5, 35-40.

Vijayakumari PK, Jacintha SV, Jacob E, Lilly RG, Rajesh R. (2014). Study on the Anti-Cancer activity of Tylophora indica leaf extracts on human colorectal cancer cells. Int J Pharm Phytochem Res. 6,355-61. 